\title{
Prosthetic joint infection in a Tunisian tertiary care teaching hospital
}

\author{
Mohamed Ben Bejeb ${ }^{1 *}$, Dhekra Chebil ${ }^{1}$, Walid Osmen ${ }^{2}$, Salah M'hamdi' ${ }^{3}$ Lamine Dhidah ${ }^{1}$ and Houyem Said-Latiri ${ }^{1}$ \\ ${ }^{1}$ Prevention and Care safety department of Sahloul Hospital - Sousse - Tunisia \\ ${ }^{2}$ Orthopedic Surgery department of Sahloul Hospital - Sousse - Tunisia \\ ${ }^{3}$ Surgical intensive care unit of Sahloul Hospital - Sousse - Tunisia
}

\begin{abstract}
Background: Prosthetic joint infections are a serious problem both in low and high income countries. Their prevention measures should be targeted by knowing the risk factors. Our study aimed to determine the incidence and current risk factors of prosthetic joint infections in our organization.

Methods: We reviewed prospectively collected data from our database on 340 patients undergoing primary and revision hip or knee and hip arthroplasty between January 2010 and December 2014.

Results: Twelve patients with infections were identified (3.5\%). Infection rates were $6.5 \%$ and $1.5 \%$ after hip and knee arthroplasty respectively. The most common organism identified was Staphylococcus aureus (6 cases). Logistic regression analysis identified three variables independently associated with prosthetic joint infection: rheumatoid arthritis (Relative Risk [RR] = 44.90; 95\% confidence interval (95\% CI): [5.54-333.0]; p <0.001) remote infections (RR = 33.17; 95\% CI: [2.57-528.7]; $\mathrm{P}=0.007)$ and revision $(\mathrm{RR}=11.57 ; 95 \% \mathrm{CI}:[1.84-71.6] ; \mathrm{p}=0.009)$.

Conclusion: Our rate seems to be higher than those reported in the literature. To reduce this rate, we must take actions targeting identified risk factors.
\end{abstract}

\section{Introduction}

Total knee (TKA) and hip arthroplasties (THA) are the most common types of prosthetic surgery. Prosthetic joints improve the quality of life, but they may fail, necessitating revision or resection arthroplasty [1]. Infection is the most serious complication occurring in 0.8 to $1.9 \%$ of knee arthroplasties [2-4] and 0.3 to $1.7 \%$ of hip arthroplasties [4-6]. Prevent this infection remains the most formidable weapon and depends on a better understanding of risk factors.

Since of decades, our country is experiencing a demographic and epidemiological transition.

These transitions were characterized by aging population, sedentary, smoking and lifestyle changes. Thus, degenerative diseases increased and joint arthroplasties became increasingly popular activities. To our knowledge, few Tunisian studies have estimated the incidence of prosthetic joint infection (PJI). Furthermore, we do not have figures reflecting the seriousness of the problem in our hospital. An evaluation of arthroplasty activities was required. Therefore, our study aimed to determine the incidence and current risk factors of PJI associated with TKA and THA.

\section{Material and methods}

\section{Setting}

Sahloul hospital is a tertiary care academic medical center in the upper Mideast of Tunisia; with 630 beds. More than 220.000 patients per year are cared for at this center. Department of Orthopedic surgery capacity was 59 beds with 5116 admissions in 2010 .

\section{Study design}

It was a retrospective study. All primary and revision TKA and THA that were performed in department of orthopedic surgery of Sahloul Hospital from January 2010 to December 2014 were included and reviewed in the study. A 12-month follow-up was conducted in all cases.

\section{Definition of prosthetic joint infection}

All cases of potential infection were identified from positive cultures in the microbiology laboratory and were cross-referenced to patients who had undergone a hip or knee replacement at the hospital. Deep infection was defined as infection within the prosthetic cavity, whereas superficial infection involved only the wound without extension deep to the fascia [7]. Infection was diagnosed per the following criteria: two or more positive culture taken from inside a prosthetic hip or knee joint, radiological or hematological evidence of infection and clinical features consistent with infection (e.g. pain. fever. restricted movement of the joint. sinus. discharge).

Correspondence to: Mohamed Ben Rejeb, Centre Hospitalo-Universitaire Sahloul Route ceinture Sahloul 4054 Sousse, Tunisie, Tel: +21654098709, Fax: +21673367451, E-mail: mohamed_benrejeb@yahoo.fr ; mohamed.benrejeb@rns.tn

Key words: prosthetic joint infection, incidence, risk factor, total knee replacement, total hip replacement

Received: September 22, 2016; Accepted: October 26, 2016; Published: October 29,2016 


\section{Potential risk factors}

The medical records of patients were abstracted for data on potential risk factors: age, gender, hypertension, diabetes mellitus, underlying native joint disease (degenerative diseases, rheumatoid rheumatoid arthritis, infection...), remote infection (Any other infection identified in preoperative period (e.g. gynecological. skin. urinary...)), immunosuppression (It is neutropenia with a rate of circulating polymorph nuclear $<500$ cells $/ \mathrm{mm}^{3}$ or another type of immunosuppression by treatments (chemotherapy. radiotherapy. immunosuppressant, corticosteroids long-term or high-dose recently) or by disease (leukemia. lymphoma. AIDS)). American Society of anesthesiologists (ASA) score, National Nosocomial Infections surveillance (NNIS) index, preoperative length of stay, antibioprophylaxis, emergency surgery and type of arthroplasty. The presence of any other risk factor was documented by the clinicians caring for the patient at the time of prosthesis implantation.

\section{Data collection and statistical analysis}

The medical records of all patients were abstracted by using a standardized data collection tool for demographic information and data related to host and index arthroplasty risk factors of PJI. The differences and similarities between categorical groups were compared using the chi-squared test (or Fisher exact tests where appropriate). Continuous variables were compared using the student $t$-test. Univariate and then multivariate regression analysis were used to examine the associations of various risk factors and PJI between patients with and without PJI. Multiple logistic regression utilizing a stepwise method of model was performed including only variables with $\mathrm{p} \leq 0.20$ in univariate regression. All analyses were conducted using SPSS version 19.0 (IBM Corporation. Armonk. NY) with significance set at the $5 \%$ level.

\section{Results}

We identified 340 arthroplasties for the study in 340 patients between 1st January 2010 and 31 December 2014 (201 TKA and 139 THA). The characteristics of patients are listed in Table 1. PJI occurred in 16 patients but four episodes were excluded from the analysis because of incomplete medical records. Therefore, 12 episodes of PJI in 12 patients were available for analysis. Thus, overall incidence rate was $3.5 \%$ (95\% CI: [1.5 - 5.5]). Infection occurred in $6.5 \%$ of patients undergoing THA (9/139) and $1.5 \%$ of patients having TKA (3/201). The most common organism identified was Staphylococcus aureus (6 cases). Microbiological findings are illustrated in table 2. Methicillinresistant Staphylococcus aureus (MRSA) $(n=2)$, third-generation Cephalosporin-resistant Klebsiella pneumonia (C3G-R) $(n=1)$ and Imipenem-resistant Acinetobacter baumannii $(n=1)$ were isolated. Univariate analysis identified as risk factors of PJI the length of stay $(\mathrm{p}=0.032)$, Rheumatoid arthritis $(\mathrm{p}=0.031)$, remote infection $(\mathrm{p}=0.007)$, NNIS index $=2(p=0.032)$, ASA score, emergency $(p<0.001)$, hip arthroplasty $(\mathrm{p}=0.032)$ and revision $(\mathrm{p}<0.001)$ (Table 3$)$. Whereas, PJI was independently associated with rheumatoïd arthritis (Relative Risk $[\mathrm{RR}]=44.90 ; 95 \%$ confidence interval (95\% CI): [5.54-333.0]; $\mathrm{p}<0.001)$, remote infections $(\mathrm{RR}=33.17 ; 95 \% \mathrm{CI}$ : [2.57-528.7]; $\mathrm{P}=$ $0.007)$ and revision $(\mathrm{RR}=11.57$; 95\% CI: [1.84-71.6]; $\mathrm{p}=0.009)$ (Table 4).

\section{Discussion}

Over the past three decades, much effort has been expended on reducing the incidence of PJI. However, recent studies reported high rates and still emphasize the acuteness and significance of this health problem $[8,9]$. Thus, several studies were carried out to examine the
Table 1. Characteristics of patients who were seen for TKA or THA at Sahloul hospital (Sousse) between 2010 and 2014.

\begin{tabular}{|c|c|c|c|}
\hline Characteristic & $\begin{array}{l}\text { TKA }(\mathbf{n}=\mathbf{2 0 1}) \\
\text { Mean or } \mathrm{n}(\%)\end{array}$ & $\begin{array}{l}\text { THA }(\mathbf{n}=139) \\
\text { Mean or } n(\%)\end{array}$ & $\begin{array}{c}\text { Total } \\
\text { Mean or } \mathrm{n}(\%)\end{array}$ \\
\hline Age (years) & $64.4 \pm 8.2$ & $54.8 \pm 15.8$ & $60.5 \pm 12.8$ \\
\hline $\begin{array}{l}\text { Male } \\
\text { Female } \\
\text { Ratio }\end{array}$ & $\begin{array}{c}48(23.9) \\
153(76.1) \\
0.31\end{array}$ & $\begin{array}{c}61(43.9) \\
78(56.1) \\
0.78\end{array}$ & $\begin{array}{c}109(32) \\
231(68) \\
0.47\end{array}$ \\
\hline Hypertension & $86(42.8)$ & $33(23.7)$ & $119(35)$ \\
\hline Diabetes & $32(15.9)$ & $18(12.9)$ & $50(14.7)$ \\
\hline \multicolumn{4}{|l|}{$\begin{array}{l}\text { Underlying native joint } \\
\text { disease }\end{array}$} \\
\hline Degenerative joint disease & $185(92)$ & $115(82.8)$ & $300(88.2)$ \\
\hline Rheumatoid arthritis & $7(3.5)$ & $14(10.1)$ & $21(6.1)$ \\
\hline Posttraumatic arthritis & $2(1)$ & $2(1.4)$ & $4(1.2)$ \\
\hline Infection (revision) & $7(3.5)$ & $8(5.7)$ & $15(4.5)$ \\
\hline Immunosuppression & $1(0.5)$ & $4(2.9)$ & $5(1.5)$ \\
\hline Remote infection & $0(0)$ & $4(2.9)$ & $4(1.2)$ \\
\hline \multicolumn{4}{|l|}{ ASA Score } \\
\hline 1 & $94(46.8)$ & $177(521)$ & $83(59.7)$ \\
\hline 2 & $5(2.4)$ & $15(4.4)$ & $10(7.2)$ \\
\hline 3 & $82(40.8)$ & $117(34.4)$ & $35(25.2)$ \\
\hline 4 & $20(10)$ & $31(9.1)$ & $11(7.9)$ \\
\hline \multicolumn{4}{|l|}{ NNIS } \\
\hline 0 & $95(47.2)$ & $87(62.5)$ & $182(53.5)$ \\
\hline 1 & $102(50.7)$ & $51(36.7)$ & $153(45)$ \\
\hline 2 & $4(2.1)$ & $1(0.8)$ & $5(1.5)$ \\
\hline $\begin{array}{l}\text { Preoperative length of stay } \\
\text { (days) }\end{array}$ & $1.9 \pm 2.9$ & $3.6 \pm 4.7$ & $2.6 \pm 3.9$ \\
\hline Total length of stay (days) & $7.35 \pm 4.6$ & $8.8 \pm 5.1$ & $7.94 \pm 4.8$ \\
\hline Antibioprophylaxis & $177(88)$ & $114(82)$ & $291(85.6)$ \\
\hline Emergency surgery & $15(7.5)$ & $18(13)$ & $33(9.7)$ \\
\hline \multicolumn{4}{|l|}{ Type of arthroplasty } \\
\hline Cemented & $63(31.3)$ & $56(40.3)$ & $119(35)$ \\
\hline Uncemented & $115(57.2)$ & $80(57.6)$ & $195(57.4)$ \\
\hline Hybrid & $23(11.4)$ & $3(2.2)$ & $26(7.6)$ \\
\hline $\begin{array}{l}\text { Number of consultation after } \\
\text { surgery }\end{array}$ & $3.88 \pm 1.2$ & $4.3 \pm 1.6$ & $4 \pm 1,3$ \\
\hline
\end{tabular}

Table 2. Microbiological findings for 12 cases with prosthetic joint infection at Sahloul hospital (Sousse) between 2010 and 2014.

\begin{tabular}{|l|c|c|c|}
\hline Bacteria & TKA $(\mathbf{n}=\mathbf{3})$ & THA $(\mathbf{n}=\mathbf{9})$ & Total $(\mathbf{n}=\mathbf{1 2})$ \\
\hline Staphylococcus aureus & 2 & 4 & 6 \\
\hline Streptococcus pneumoniae & 0 & 1 & 1 \\
\hline Klebsiella pneumoniae & 0 & 2 & 2 \\
\hline Proteus mirabilis & 0 & 1 & 1 \\
\hline Acinetobacter baumanni & 1 & 0 & 1 \\
\hline Not identified & 0 & 1 & 1 \\
\hline
\end{tabular}

incidence of infections after THA and TKA and determine their risk factors. It is admitted that the rate of these infections depends on the activities of the center, monitoring mode, sample size and underlying diseases. Moreover, direct comparisons between different studies are not reliable and easy because of considerable difference in methodology, definitions of PJI and type of prosthesis used [10].

Our rates were higher than those reported by several studies. The lowest incidences have been reported in Scandinavian countries. Infection occur in 0.3 to $0.6 \%$ of patients with THA [10,11] and 0.52 to $1 \%$ of patients undergoing TKA $[10,12]$. Low rates were also found in United Kingdom [6], Germany [13], USA [4,8] The majority of these studies were based on epidemiological surveillance programs or registries already in place $[2,6,10-12,14]$. Even such routine surveillance 
Table 3. Univariate analysis of risk factors of prosthetic joint infection in Sahloul hospital of Sousse (Tunisia).

\begin{tabular}{|c|c|c|c|c|}
\hline Factor & $\begin{array}{c}\text { Infection } \\
(\mathrm{n}=12) \\
\text { Mean or } \mathrm{n}(\%)\end{array}$ & $\begin{array}{c}\text { No infection } \\
(\mathrm{n}=328) \\
\text { Mean or } \mathrm{n}(\%)\end{array}$ & RR [CI 95\%] & $\mathbf{p}$ \\
\hline Age & $65.5 \pm 15$ & $60 \pm 12.7$ & $1.03[0.98-1.08]$ & 0.27 \\
\hline 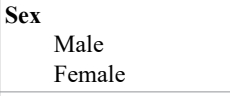 & $\begin{array}{l}5(4.6) \\
7(3)\end{array}$ & $\begin{array}{l}104(95.4) \\
224(97)\end{array}$ & $1.51[0.49-4.66]$ & 0.68 \\
\hline \begin{tabular}{|c|} 
Hypertension \\
Yes \\
No \\
\end{tabular} & $\begin{array}{l}5(4.2) \\
7(3.2)\end{array}$ & $\begin{array}{l}114(95.8) \\
214(96.8)\end{array}$ & $1.33[0.43-4.08]$ & 0.85 \\
\hline $\begin{array}{c}\text { Diabetes } \\
\text { Yes } \\
\text { No }\end{array}$ & $\begin{array}{c}3(6) \\
9(3.1)\end{array}$ & $\begin{array}{c}47(94) \\
281(96.9\end{array}$ & 1.93 [0.54-6.9] & 0.39 \\
\hline \begin{tabular}{|l} 
Rheumatoidarthritis \\
Yes \\
No
\end{tabular} & $\begin{array}{l}3(14.3) \\
9(2.8)\end{array}$ & $\begin{array}{c}18(85.7) \\
310(97.2)\end{array}$ & $5.06[1.48-17.32]$ & 0.031 \\
\hline \begin{tabular}{|l} 
Immunosuppression \\
Yes \\
No
\end{tabular} & $\begin{array}{c}1(20) \\
11(3.3)\end{array}$ & $\begin{array}{c}4(80) \\
324(96.7)\end{array}$ & $6.1[0.96-38.6]$ & 0.16 \\
\hline $\begin{array}{c}\text { Remote infection } \\
\text { Yes } \\
\text { No }\end{array}$ & $\begin{array}{l}2(50) \\
10(3)\end{array}$ & $\begin{array}{c}2(50) \\
326(97)\end{array}$ & $16.8[5.3-53.3]$ & 0.007 \\
\hline \begin{tabular}{|c|} 
ASA Score \\
1 \\
2 \\
3 \\
4 \\
\end{tabular} & $\begin{array}{l}2(1.1) \\
3(20) \\
4(3.4) \\
3(9.7)\end{array}$ & $\begin{array}{c}175(98.9) \\
12(80) \\
113(96.6) \\
28(90.3)\end{array}$ & $\begin{array}{c}1 \\
21.8[3.3-143.7] \\
3.1[0.56-17.2] \\
9.37[1.5-58.6]\end{array}$ & $\begin{array}{c}- \\
0.001 \\
0.19 \\
0.017\end{array}$ \\
\hline \begin{tabular}{|c} 
NNIS index \\
0 \\
1 \\
2
\end{tabular} & $\begin{array}{l}3(1.6) \\
8(5.2) \\
1(20)\end{array}$ & $\begin{array}{c}179(98.4) \\
145(94.8) \\
4(80)\end{array}$ & $\begin{array}{c}1 \\
3.29[0.86-12.5] \\
14.9[1.26-176.4]\end{array}$ & $\begin{array}{c}- \\
0.082 \\
0.032\end{array}$ \\
\hline $\begin{array}{l}\text { Preoperativelength } \\
\text { of stay }\end{array}$ & $3.9 \pm 4.3$ & $2.6 \pm 3.8$ & $1.1[0.95-1.2]$ & 0.25 \\
\hline \begin{tabular}{|c|} 
Prosthesis site \\
Hip \\
Knee
\end{tabular} & $\begin{array}{l}9(6.5) \\
3(1.5)\end{array}$ & $\begin{array}{l}130(93.5) \\
198(98.5)\end{array}$ & $4.57[1.21-17.2]$ & 0.032 \\
\hline $\begin{array}{l}\text { Antibioprophylaxis } \\
\text { Yes } \\
\text { No }\end{array}$ & $\begin{array}{l}9(3.1) \\
3(6.1)\end{array}$ & $\begin{array}{c}282(96.9) \\
46(93.9)\end{array}$ & $0.5[0.14-1.80]$ & 0.39 \\
\hline $\begin{array}{l}\text { Emergency surgery } \\
\text { Yes } \\
\text { No }\end{array}$ & $\begin{array}{c}6(18.2) \\
6(2)\end{array}$ & $\begin{array}{l}27(81.8) \\
301(98)\end{array}$ & $9.3[3.18-27.21]$ & $<0.001$ \\
\hline $\begin{array}{r}\text { Revision } \\
\text { Yes } \\
\text { No }\end{array}$ & $\begin{array}{l}3(20) \\
9(2.8)\end{array}$ & $\begin{array}{c}12(80) \\
316(97.2)\end{array}$ & $7.22[2.18-24]$ & $<0.001$ \\
\hline Total length of stay & $11.2 \pm 6.3$ & $7.8 \pm 4.8$ & $1.08[1.01-1.16]$ & 0.032 \\
\hline
\end{tabular}

Table 4. Multivariate analysis of risk factors of prosthetic joint infection in Sahloul hospital of Sousse.

\begin{tabular}{|l|c|c|c|}
\hline Factor & Adjusted RR & $\mathbf{9 5 \% C I}$ & p \\
\hline Rheumatoidarthritis & 42.90 & {$[5.54-333]$} & $<0.001$ \\
\hline Remote infection & 38.17 & {$[2.75-528.7]$} & 0.007 \\
\hline Revision & 11.50 & {$[1.84-71.6]$} & 0.009 \\
\hline
\end{tabular}

seems to be insensitive in detecting PJIs [15]. Thus, combining data from different sources and a manual review of all identified patient records probably leads to the most reliable recording of infectious complications and helps to classify them correctly [14]. Earlier studies that base their infection rates on routine recording of septic complications may therefore have underestimated the true infection burden $[12,14]$. Moreover, Well-executed studies examining factors associated with infection after joint replacement are difficult to conduct. Prospective studies with meticulous collection of data have problems in achieving sufficient numbers to be effectively statistically powerful because infection is a rare event [16]. Large registry-based studies often rely on readmission or re-operation as a surrogate measure of infection and hence miss numerous infections successfully treated conservatively
[16]. Finally, the results of studies estimating its incidence have been conflicting [17]. Moreover, there are no standard criteria available to how infection is both defined and identified. Isolating a microorganism on tissue biopsies cultures was regarded as gold standard [18]; however, certain authors have instead used histological criteria [19] and it is well known that there are false negatives among the culture results.

In present study, $58 \%$ of isolated micro-organisms were Gram Positive Cocci. Of them, Staphylococcus aureus was the most common. It was resistant to methicillin (MRSA) in 33\% of cases. Our results are consistent with those reported in the literature. However, our proportion of MRSA was significantly higher. It has been reported that many bacteria can cause PJIs, but Staphylococcus aureus, including MRSA, and coagulase-negative staphylococci (CNS) such as Staphylococcus epidermidis were the most common infecting organism [3,20,21]. Furthermore, MRSA rate varies considerably through the world. MRSA is isolated in $8 \%$ to $30 \%$ of patients with PJI in Europe and USA $[4,22,23]$. The highest rate was reported by Choong et al. (64.2\%) in Australia [5]. Nowadays, the authors are currently worried about the increasing proportions of infections with Gram-negative bacilli such as Pseudomonas aeruginosa and Escherichia Coli [24,25].

Rheumatoid arthritis, remote infection and revision were the independent risk factors of PJI in our study. Since the 80s, several studies incriminated inflammatory arthritis especially rheumatoid arthritis in the genesis of infection after THA or TKA [26-29]. Rheumatoid arthritis trend to increase from 2.5 to 4 times the risk of developing this infectious disease [30,31]. Positive association could be related to the defect in the immune system caused by this underlying disease and its treatment. Corticosteroids are known to increase the risk of such infection [32,33] but the effect of new anti- rheumatoid therapy not been clearly elucidated $[34,35]$. The second patient related factor in our study was active infections identified in preoperative period. Any remote infections especially those affecting the skin, genital, unary tract and oro-rhino-laryngeal sphere increase the risk of PJI through bacteremia [36]. Thus, remote infection sources must be detected and eradicated before surgery.

On the other hand, revision was the operation-related risk factor in present study. Hanssen et al. [37] concluded that the rates of PJI were higher after revision than after primary TKA and THA. While between $1.5 \%$ and $2.5 \%$ of patient undergoing primary joint replacement developed PJI, the infection rates were $3.2 \%$ and $5.6 \%$ after revision for THA and TKA respectively [37]. High risk of infection could be related to the quality of joint aspiration fluid procedure. Joint aspiration prior to revision arthroplasty is widely utilized. For knee patients the procedure is comparatively straightforward, whereas hip aspiration may impose a higher risk of iatrogenic infection [38]. Thus, it is often argued that invasive diagnostic samples from hip patients should be obtained only if a there is a high probability of infection $[39,40]$.

Present study has a number of limitations. We did not include enough infected patients and our study was mono-centric. Thus, the results should not be generalized to other settings. The choice of 12 months' follow-up could underestimate the incidence rate of PJI in our study. In fact, late infections caused by slow multiplication microorganisms and occurred beyond this deadline may not be counted. Unfortunately, due to retrospective design of our study, it was not possible to assess the role of all risk factors and collect data was limited to those found in patients' records. Many potential confounding factors of comorbidities such as obesity, malignancy, malnutrition, smoking, alcohol, blood transfusion and operating room 
environment were not studied. These factors have been suggested to be associated with an increased risk of PJI.

\section{Conclusion}

In present study, infection rate seems to be higher than those reported by several studies. This confirms that PJI is a public health issue in developing countries such Tunisia and leads us to establish as soon as possible a strategy to promote joint replacement activities in our hospital. The utility of this study is to target our improvement actions. Those actions should be interested patients with Rheumatoid arthritis or remote infection and those undergoing a revision.

\section{Disclosure of interest}

The authors declare that they have no conflicts of interest concerning this article.

\section{References}

1. Del Pozo JL, Patel R (2009) Clinical practice. Infection associated with prosthetic joints. $N$ Engl J Med 361: 787-794. [Crossref]

2. Jämsen E, Huhtala H, Puolakka T, Moilanen T (2009) Risk factors for infection after knee arthroplasty. A register-based analysis of 43,149 cases. J Bone Joint Surg Am 91: 38-47. [Crossref]

3. Peersman G, Laskin R, Davis J, Peterson M (2001) Infection in total knee replacement: a retrospective review of 6489 total knee replacements. Clin Orthop Relat Res 15-23. [Crossref]

4. Pulido L, Ghanem E, Joshi A, Purtill JJ, Parvizi J (2008) Periprosthetic joint infection: the incidence, timing, and predisposing factors. Clin Orthop Relat Res 466: 1710-1715. [Crossref]

5. Choong PF, Dowsey MM, Carr D, Daffy J, Stanley P (2007) Risk factors associated with acute hip prosthetic joint infections and outcome of treatment with a rifampinbased regimen. Acta Orthop 78: 755-765. [Crossref]

6. Phillips JE, Crane TP, Noy M, Elliott TS, Grimer RJ (2006) The incidence of deep prosthetic infections in a specialist orthopaedic hospital: a 15-year prospective survey. J Bone Joint Surg Br 88: 943-948. [Crossref]

7. Abudu A, Sivardeen KA, Grimer RJ, Pynsent PB, Noy M (2002) The outcome of perioperative wound infection after total hip and knee arthroplasty. Int Orthop 26: 4043. [Crossref]

8. Kurtz SM, Ong KL, Lau E, Bozic KJ, Berry D, et al. (2010) Prosthetic joint infection risk after TKA in the Medicare population. Clin Orthop Relat Res 468: 52-56. [Crossref]

9. Dale H, Hallan G, Hallan G, Espehaug B, Havelin LI, et al. (2009) Increasing risk of revision due to deep infection after hip arthroplasty. Acta Orthop 80: 639-645. [Crossref]

10. Pedersen AB, Svendsson JE, Johnsen SP, Riis A, Overgaard S (2010) Risk factors for revision due to infection after primary total hip arthroplasty. A population-based study of 80,756 primary procedures in the Danish Hip Arthroplasty Registry. Acta Orthop 81: 542-547. [Crossref]

11. Jämsen E, Furnes O, Engesaeter LB, Konttinen YT, Odgaard A, et al. (2010) Prevention of deep infection in joint replacement surgery. Acta Orthop 81: 660-666. [Crossref]

12. Jämsen E, Huotari K, Huhtala H, Nevalainen J, Konttinen YT (2009) Low rate of infected knee replacements in a nationwide series - is it an underestimate? Review of the Finnish Arthroplasty Register on 38,676 operations performed in 1997 through 2003. Acta Orthopaedica 80: 205-212.

13. Claus A, Asche G, Brade J, Bosing-Schwenkglenks M, Horchler H, et al. (2006) Risk profiling of postoperative complications in 17,644 total knee replacements. Unfallchirurg 109: 5-12 [Article in German]. [Crossref]

14. Jämsen E, Varonen M, Huhtala H, Lehto MU, Lumio J, et al. (2010) Incidence of prosthetic joint infections after primary knee arthroplasty. $J$ Arthroplasty 25: 87-92. [Crossref]

15. Huotari K, Agthe N, Lyytikäinen O (2007) Validation of surgical site infection surveillance in orthopedic procedures. Am J Infect Control 35: 216-221. [Crossref]

16. Willis-Owen CA, Konyves A, Martin DK (2010) Factors affecting the incidence of infection in hip and knee replacement: an analysis of 5277 cases. J Bone Joint Surg Br

\section{2: 1128-1133. [Crossref]}

17. Urquhart DM, Hanna FS, Brennan SL, Wluka AE, Leder K, et al. (2010) Incidence and risk factors for deep surgical site infection after primary total hip arthroplasty: a systematic review. J Arthroplasty 25: 1216-1222. [Crossref]

18. Banit DM1, Kaufer H, Hartford JM (2002) Intraoperative frozen section analysis in revision total joint arthroplasty. Clin Orthop Relat Res 230-238. [Crossref]

19. Atkins BL, Athanasou N, Deeks JJ, Crook DW, Simpson H, et al. (1998) Prospective evaluation of criteria for microbiological diagnosis of prosthetic-joint infection at revision arthroplasty. The OSIRIS Collaborative Study Group. J Clin Microbiol 36: 2932-2939. [Crossref]

20. Ure KJ, Amstutz HC, Nasser S, Schmalzried TP (1998) Direct-exchange arthroplasty for the treatment of infection after total hip replacement. An average ten-year followup. J Bone Joint Surg Am 80: 961-968. [Crossref]

21. Jackson WO1, Schmalzried TP (2000) Limited role of direct exchange arthroplasty in the treatment of infected total hip replacements. Clin Orthop Relat Res 101-105. [Crossref]

22. Parvizi J1, Ghanem E, Azzam K, Davis E, Jaberi F, et al. (2008) Periprosthetic infection: are current treatment strategies adequate? Acta Orthop Belg 74: 793-800. [Crossref]

23. Moran E, Masters S, Berendt AR, McLardy-Smith P, Byren I, et al. (2007) Guiding empirical antibiotic therapy in orthopedics: The microbiology of prosthetic joint infection managed by debridement, irrigation and prosthesis retention. J Infect 55: 1-7. [crokssref]

24. Peel TN, Cheng AC, Buising KL, Choong PF (2012) The microbiological aetiology, epidemiology and clinical profile of prosthetic joint infections: are current antibiotic prophylaxis guidelines effective? Antimicrobial Agents and Chemotherapy 56: 2386 2391.

25. Zimmerli W, Trampuz A, Ochsner PE (2004) Prosthetic-joint infections. N Engl J Med 351: 1645-1654. [Crossref]

26. Salvati EA, Robinson RP, Zeno SM, Köslin BL, Brause BD, et al. (1982) Infection rates after 3175 total hip and total knee replacements performed with and without a horizontal unidirectional filtered air-flow system. J Bone Joint Surg Am 64: 525-535. [Crossref]

27. Wilson MG, Kelley K, Thornhill TS (1990) Infection as a complication of total kneereplacement arthroplasty. Risk factors and treatment in sixty-seven cases. $J$ Bone Joint Surg Am 72: 878-883. [Crossref]

28. Schrama JC, Espehaug B, Hallan G, Engesaeter LB, FurnesO, et al. (2010) Risk of revision for infection in primary total hip and knee arthroplasty in patients with rheumatoid arthritis compared with osteoarthritis: a prospective, population-based study on 108,786 hip and knee joint arthroplasties from the Norwegian Arthroplasty Register. Arthritis Care Res (Hoboken) 62: 473-479. [Crossref]

29. Ravi B, Escott B, Shah PS, Jenkinson R, Chahal J, et al. (2012) A systematic review and meta-analysis comparing complications following total joint arthroplasty for rheumatoid arthritis versus for osteoarthritis. Arthritis Rheum 64: 3839-3849. [Crossref]

30. Bengtson S, Knutson K (1991) The infected knee arthroplasty. A 6-year follow-up of 357 cases. Acta Orthop Scand 62: 301-311. [Crossref]

31. Poss R, Thornhill TS, Ewald FC, Thomas WH, Batte NJ, et al. (1984) Factors influencing the incidence and outcome of infection following total joint arthroplasty Clin Orthop Relat Res 117-126. [Crossref]

32. Wu C, Qu X, Liu F, Li H, Mao Y, et al. (2014) Risk factors for periprosthetic join infection after total hip arthroplasty and total knee arthroplasty in Chinese patients. PLoS One 9: e95300. [Crossref]

33. Bernatsky S, Hudson M, Suissa S (2007) Anti-rheumatic drug use and risk of serious infections in rheumatoid arthritis. Rheumatology (Oxford) 46: 1157-1160. [Crossref]

34. den Broeder AA, Creemers MC, Fransen J, de Jong E, de Rooij DJ, et al. (2007) Risk factors for surgical site infections and other complications in elective surgery in patients with rheumatoid arthritis with special attention for anti-tumornecrosis factor: a large retrospective study. J Rheumatol 34: 689-695. [Crossref]

35. Giles JT, Bartlett SJ, Gelber AC, Nanda S, Fontaine K, et al. (2006) Tumor necrosis factor inhibitor therapy and risk of serious postoperative orthopedic infection in rheumatoid arthritis. Arthritis Rheum 55: 333-337. [Crossref]

36. Migaud H, Senneville E, Gougeon F, Marchetti E, Amzallag M, et al. (2005) Risque infectieux en chirurgie orthopédique. EMC-Rhumatologie Orthopédie 2: 151-172. [Article in French] 
37. Hanssen AD, Rand JA, (1999) Evaluation and treatment of infection at the site of a total hip or knee arthroplasty. Instr Course Lect 48: 111-122. [Crossref]

38. Schäfer P, Fink B, Sandow D, Frommelt L, (2012) Infections in Hip and Knee Arthroplasty: Challenges to and Chances for the Microbiological Laboratory. In: Samo Fokter. Recent Aadvances in Arthroplasty: Rijeka/Croatia: InTech 449-458.
39. Bozic KJ, Kurtz SM, Lau E, Ong K, Vail TP, et al. (2010) The epidemiology of revision total hip arthroplasty in the United States. J Bone Joint Surg Am 91: 128-133. [Crossref]

40. Bozic KJ, Kurtz SM, Lau E, Ong K, Chiu V, et al. (2010) The epidemiology of revision total knee arthroplasty in the United States. Clin Orthop Relat Res 468: 45-51. [Crossref]

Copyright: (C2016 Bejeb MBB. This is an open-access article distributed under the terms of the Creative Commons Attribution License, which permits unrestricted use, distribution, and reproduction in any medium, provided the original author and source are credited. 